\title{
INFLUENCE OF METEOROLOGICAL VARIABLES TO WATER QUALITY IN FIVE LAKES OVER THE AGGTELEK (HUNGARY) AND SLOVAK KARST REGIONS - A CASE STUDY
}

\author{
VPLIV METEOROLOŠKIH SPREMENLJIVK NA KAKOVOST VODE \\ V PETIH JEZERIH KRAŠKIH REGIJ AGGTELEK (MADŽARSKA) \\ IN SLOVAŠKE - ŠTUDIJSKI PRIMERI
}

\author{
Andrea SAMU ${ }^{1}$, Zoltán CSÉPE ${ }^{1} \&$ Ilona BÁRÁNY-KEVEI ${ }^{1}$
}

\begin{abstract}
UDC 556.551:551.5(437.6+439)

Andrea Samu, Zoltán Csépe \& Ilona Bárány-Kevei: Influence of meteorological variables to water quality in five lakes over the Aggtelek (Hungary) and Slovak karst regions - a case study

The main objective of this study is to analyse the effect of tendencies in the meteorological variables on the water quality on the example of five lakes in the Aggtelek and Slovak karst. The data set used eleven water quality parameters (oxygen saturation, chemical oxygen demand, nitrate, nitrite, orthophosphate, total phosphorus, ammonium, $\mathrm{pH}$, conductivity, iron, manganese), as well as daily data of six climatic parameters from the period 2008-2010. A cluster analysis is performed in order to determine the climate impact on the water quality parameters. Furthermore, factor analysis with special transformation, as a novelty in the study, is implemented to find out the weight of the climate parameters as explanatory variables and hence their rank of importance in forming the given water quality parameter as an influencing variable. The study introduces a methodology for analysing the climate impact on the water quality parameters. In order to reduce the number of the water quality parameters, a so called two-stage factor analysis was performed, which is a novel procedure. Application of the two-stage factor analysis involves both benefits and disadvantages. Its benefit is that it substantially reduces the number of resultant variables. In this way, information loss of the retained factors is around $20 \%$. As a result, we received that both positive and negative extreme values of water quality parameters can be associated with weak or breaking-up warm fronts passing through over the region. On the contrary, the role of anticyclones or anticyclone ridge weather situations is supposed to be irrelevant. Unstable and extreme weather conditions act in the direction of breaking up the balance that would support the good water quality. This process does not benefit the water use nor the sensitive karst hydrogeological system.

Keywords: karstic lakes, eutrophication, water quality, meteorological variables, cluster analysis, ranked factor analysis.
\end{abstract}

Izvleček UDK 556.551:551.5(437.6+439) Andrea Samu, Zoltán Csépe \& Ilona Bárány-Kevei: Vpliv meteoroloških spremenljivk na kakovost vode $v$ petih jezerih kraških regij Aggtelek (Madžarska) in Slovaške - študijski primeri

Glavni cilj te študije je analizirati vpliv trendov meteoroloških spremenljivk na kakovost vode na primeru petih jezer v krasu Aggtelek in v slovaškem krasu. Študija temelji na enajstih parametrih kakovosti vode (nasičenost s kisikom, kemično potrebo po kisiku, nitrat, nitrit, ortofosfat, skupni fosfor, amoniak, $\mathrm{pH}$, električna prevodnost, železo, mangan), kot tudi na dnevnih podatkih šestih podnebnih parametrov $\mathrm{v}$ obdobju 2008-2010. S pomočjo analize grozdenja smo določili podnebne vplive na parametre kakovosti vode. Izvedli smo tudi modificirano faktorsko analizo, ki je novost te študije, da bi lahko določili težo podnebnih parametrov kot pojasnjevalne spremenljivke in s tem njihov razred pomena pri oblikovanju danega parametra kakovosti vode kot vplivanje na spremenljivko. Študija uvaja metodologijo za analizo vplivov podnebnih parametrov na kakovost vode. Da bi zmanjšali število parametrov kakovosti vode, je bila izvedena tako imenovana analiza dvostopenjskega faktorja, kar je nov postopek. Uporaba analize dvostopenjskega faktorja vključuje tako prednosti kot pomanjkljivosti. Njegova prednost je, da se bistveno zmanjša število posledičnih spremenljivk. Na ta način se izgubi okrog $20 \%$ informacij ohranjenih dejavnikov. $\mathrm{Na}$ ta način so lahko tako pozitivne in negativne ekstremne vrednosti parametrov kakovosti vode povezane s šibkimi ali razpadajočimi toplimi frontami, ki prečkajo regijo. Nasprotno pa naj bi bile vloge anticiklonov ali anticiklonskih grebenov nepomembne. Nestabilne in ekstremne vremenske razmere delujejo v smeri razpada ravnovesja, ki bi podprlo dobro kakovost vode. Ta proces ne koristi porabi vode niti občutljivim kraškim hidrogeološkim sistemom.

Ključne besede: kraška jezera, evtrofikacija, kakovost vode, meteorološke spremenljivke, analiza grozdenja, faktorske analize.

\footnotetext{
${ }^{1}$ Department of Climatology and Landscape Ecology, University of Szeged, HU-6701 Szeged, P.O.B. 653, Hungary,

E-mail: samu.andrea@geo.u-szeged.hu
}

Received/Prejeto: 14.11.2011 


\section{INTRODUCTION}

Eutrophication of surface waters has emerged heavily from the middle of the 20th century. The nutrient input caused by human activities have led to decline in water quality, which was indicated firstly by loosing some functions of these water bodies, and substantially overturning their role in the ecosystem (Vollenweider 1968; Lund 1970; Dillon \& Rigler 1974; Oglesby \& Schaffner 1975; OECD 1982; Vollenweider \& Kerekes 1982, etc.). This phenomenon was also observable in many karst areas of the world. The process on these sensitive areas is quite problematic from more aspects. In karstic areas water has determinative role in forming the karst system. The high permeability of rocks results in high infiltration rates, which influences quality of subsurface waters as well as flora and fauna of caves. Karstic depressions (containing smaller or bigger lakes as well) can mediate pollution to the deeper regions quite effective. The existence of these shallow lakes is also endangered, since decline in water quality can be followed by their siltation (Samu et al. 2010).

Climate change, as a widely studied natural phenomenon with an ever increasing human impact, facilitates among other effects a growing frequency of the climate extremities. This induces also changes in water balance, concerning both quality and quantity (Horváth 2009, 2010). The effect of the changing climate on the realignment of the water resources and water quality can be a significant task for the future water management (IPCC 2007). Together with the worse water quality the various water use possibilities are reducing and the original ecosystem is changing. On the karst areas it has some more specific effects like possible contamination of cave systems (Haviarová et al. 2010) and drinking water resources or water demand on the dry karst plateaus which is an efficient help in the agriculture (Kunský 1939).

On the study area, a very quick filling up of the lake depressions has been detected since the early 1980s. Former investigations have dealt with the reasons of the accelerated eutrophication and disappearing of these lakes and the authors reported four main causes of this phenomenon; namely intensified agriculture, no sewage treatment, geological reasons and climate extremities (Tereková 1984; Háberová \& Karasová 1991; Hudec et al. 1993; Hudec et al. 1995; Kaliser 1995; Cílek 1996; Bárány-Kevei 1999; Czesznak 2000; Barančok 2001; Terek 2003; Gaál 2010; Kilík 2010). In this study we analyze the effect of the weather conditions.

The main objective of this paper is to analyse the effect of extreme values of the meteorological parameters on the water quality on the example of five lakes in the Aggtelek and Slovak karst. A cluster analysis is performed in order to determine the climate impact on the water quality parameters. Furthermore, factor analysis with special transformation is implemented to find out the weight of the climate parameters as explanatory variables and hence their rank of importance in forming the given water quality parameter as influencing variable.

\section{MATERIALS AND METHODS}

The study area is located in North-eastern Hungary and South-eastern Slovakia, in Hungary named Aggtelek karst and in Slovakia named Slovak karst but it is a geologically and geographically uniform karst plateau, historically called Gömör-Tornai-karst (Fig. 1).

The climate of the study area is humid continental with a long summer and, as a reason of the vicinity of the Carpathians, with a strong mountain effect (Ujvárosy 1998). The mean annual temperature was in the period of $1958-19839,1{ }^{\circ} \mathrm{C}$ and the annual precipitation is according to Hungarian Meteorological Service between 1941-1970 at Jósvafö $680 \mathrm{~mm}$. This amount reduced in last years. From the 1980's number and intensity of dry periods is growing compared to previous years while number of humid periods reduced. From the years 2000 this tendency seems to be slighter, but this can refer about the quick occurance of the two extremities after each other. It was determined, that the annual sum of the precipitation doesn't show clear tendency in the examined period. After the visible reducing in less extent in the 1980's became the weather from the middle of 1990's wetter again. Moreover from the beginning of the 1970's there were no years with extrem precipitation values (more than $800 \mathrm{~mm}$ ), while the dry years (less than $500 \mathrm{~mm}$ ) occured with the same frequency as before (Tanács \& Bárány-Kevei 2010; Tanács 2011). Fig. 2 shows dry and wet periods between 1980 and 2010, the examined period of 2008 and 2010 is emphasized.

The lakes on this karst area have geomorphological origin: various karst depressions became obstructed with impermeable material (Kunský 1939; Barančok 2001), there are some relatively impermeable lenses of Lower 


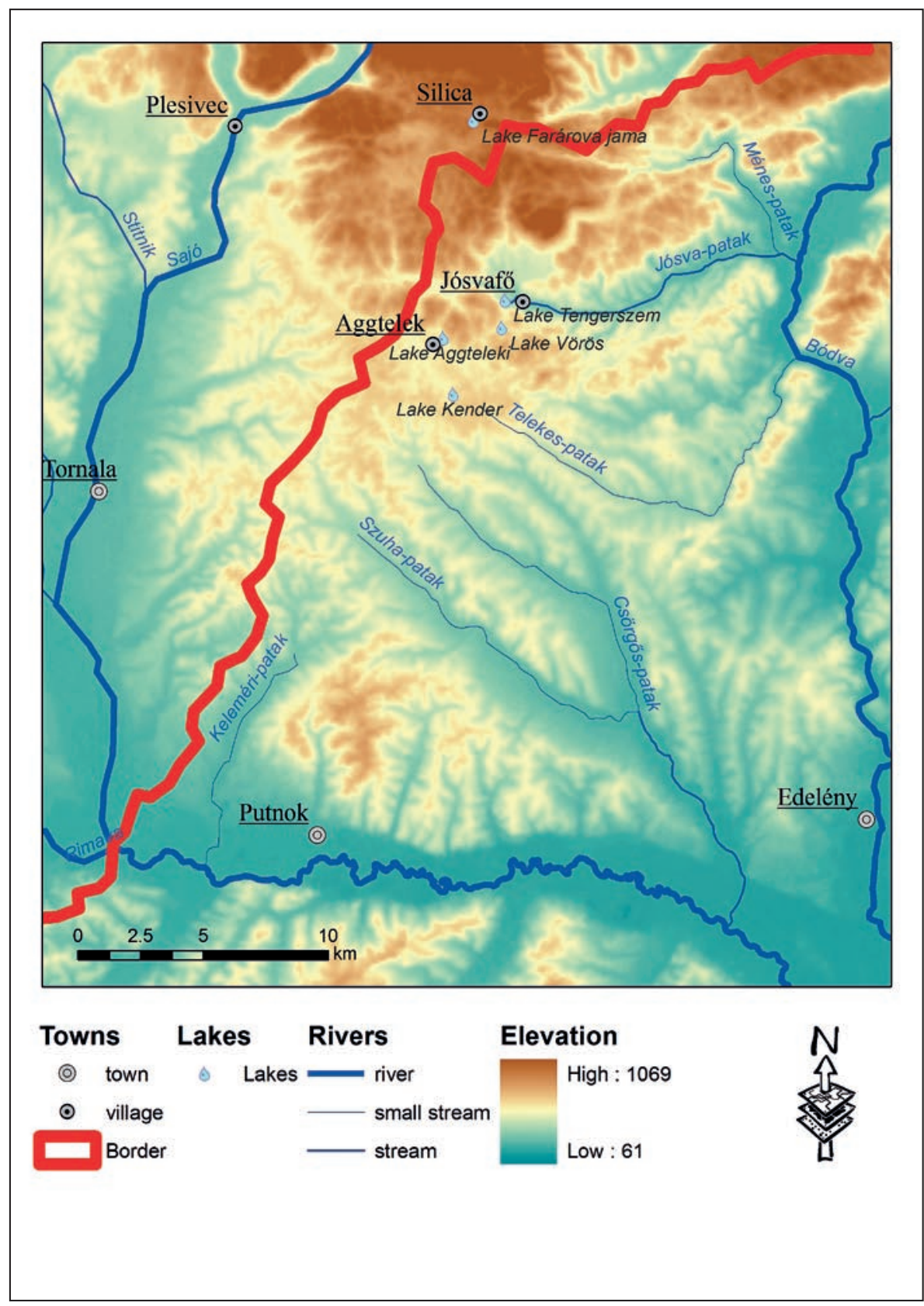

Fig. 1: Location of the study area and the lakes.

Triassic shale layers near strongly karstified Middle Triassic limestones (Malík 2006). Some of them are naturally arisen but several of them are of human origin or clogged up with human help.

The Lake Aggteleki is situated in the north-eastern part of Aggtelek village (Hungary) and it is quite affected by human activity. Its area is one-fourth of the original size and it was reduced only in the last 20-25 years (Kunský 1939): its original area is 1.13 ha, while today its area is round $0.3 \mathrm{ha}$ ). According to Barančok (2001) the lake could preserve the extension of its water during a relatively long period. A road runs near the southern shore of the lake, while on the western and northern sides there are houses with gardens. The east side is closed by the Tó-mountain karrenfield. Its water supply comes from precipitation directly or indirectly as inflow from the road, from the Tó-mountain and from the village. The lake started to completely loose it's free water surface so in 2002 it was dredged and the sludge was deposited next to the lake's direct vicinity.

The Lake Kender is situated south-east from Aggtelek village (Hungary). Its surroundings are probably the most natural, there is a small forest, a bit further away a pasture and it is surrounded by fields situated at lower elevations. The place of the Kender-lake was used for about 1000 years by iron furnaces (Jakucs 2001). This activity required water and probably that was the reason why a fortress was built in this place that could collect water from precipitation. In the 1960s water of the Lake Kender was used for hemp soaking and nowadays for watering cattle. Its water supply comes only from the precipitation.

The Lake Vörös (with an area of about 0.77 hectare, Kunský (1939)) is south-west from village Jósvafö (Hungary) in a doline of which the surface was covered with red clay. In 2001 it was dredged out. Its only water supply comes from precipitation being the main risk for the lake. The road in its vicinity blocked precipitation from inflowing to the lake resulting in a serious decrease in the water level. According to Huber (2006) several protected species (e.g. Coenagrion scitulum and Coenagrion vernale) extincted during that time. The state of this lake has been stabilized, since the National Park built a water supply system from the road (including an oil filter). 


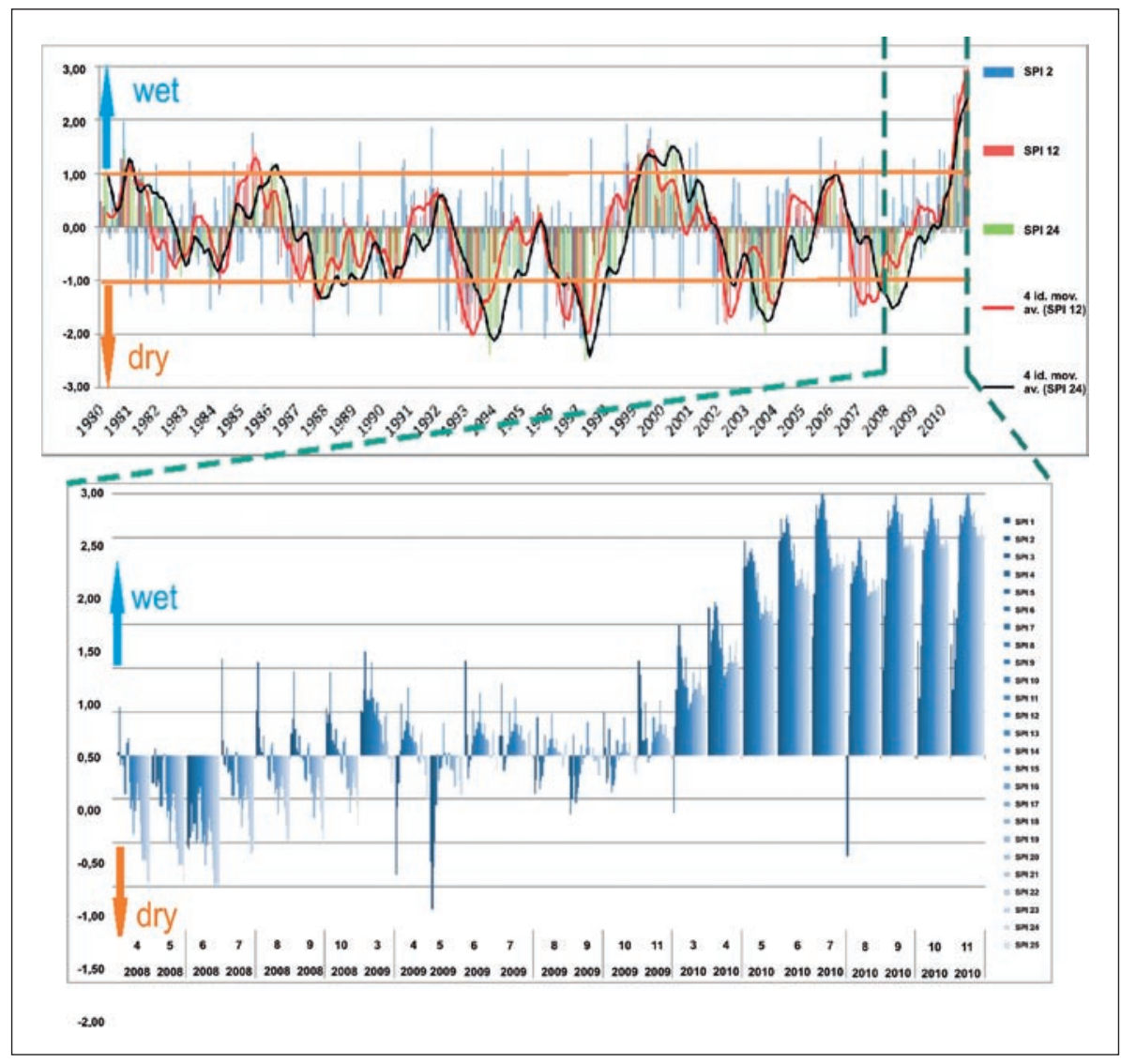

Fig.2: Wet and dry periods on the Aggtelek karst area between 2008-2010 according to the SPI severity drought index (McKee et al. 1993).

The biggest of the lakes studied is the Lake Papverme (or Lake Farárová jama), located in Slovakia south-east from Szilice village at a lower elevation. Its area is around 1 hectare. There is a road on the northern side of the lake. Directly on the north-west bank of the lake there is an agricultural settlement. On its western side there are agricultural fields and the village itself, while on the eastern side of the lake farms and in the south a forest can be found. Line-fishing is intensive; nevertheless, the amount of waste on the coast is notable. According to Hudec et al. (1993) in the year 1992 the lake was strongly eutrophicated.

The Lake Tengerszem was artificially created above the village of Jósvafö (Hungary) in 1942 by damming the Jósva spring coming from the Baradla cave. Its aim was to insure a power source for the cave (Juhász \& Salamon 2006). The lake gets its water supply from the Jósva spring and it has an outflow further through the village Jósvafö.

Table 1. summarizes the results of the water quality monitoring process between 2008 and 2010.

Barančok (2001) examined the reducing level of the Lake Gyökérréti (Jašteričie) and the sums of precipitation between 1931-1980 and 1981-1998. He established that annual mean precipitation for the period 1981-1998 decreased compared to the period 1931-1960. At the same time Tanács \& Bárány-Kevei (2010) dealt with precipitation trends associated with the region.

The monitoring of the water quality of the lake was carried out monthly (except the winter months because of the freezing) over the period 2008-2010. The test holes were fixed up in the points of the compass in the near of the coast $(\sim 2 \mathrm{~m})-$ in 2 and 4 directions and in 0.5 $m$ depth (because of the shallowness of the lakes was not a big deviance with the deeper regions).

The parameters used with their (unit, number of measurements, measure standards) are as follows: the indices of the oxygen establishment (oxygen saturation, $\mathrm{O}_{2}, \%, 362$ measurements; chemical oxygen demand, COD, mg.litre ${ }^{-1}, 345$ measurements, MSZ ISO 6060:1991), the indices of the phosphate-nitrate establishment (nitrate, $\mathrm{NO}_{3}, \mathrm{mg} \cdot$ litre ${ }^{-1}, 418$ measurements; nitrite, $\mathrm{NO}_{2}$, mg.litre ${ }^{-1}, 300$ measurements, MSZ EN ISO 13395:1999), ortophosphate $\left(\mathrm{PO}_{4}, \mathrm{mg} \cdot\right.$ litre $^{-1}, 415$ measurements), total phosphorus (TP, mg.litre ${ }^{-1}, 299$ measurements, MSZ EN ISO 15681-1:2005), ammonium $\left(\mathrm{NH}_{4}, \mathrm{mg} \cdot \mathrm{litre}^{-1} ; 376\right.$ measurements, MSZ EN ISO 11732:2005), $\mathrm{pH}$ (392 measurements), conductivity (G, $\mu \mathrm{S} \cdot \mathrm{cm}^{-1} ; 392$ measurements), iron (Fe, $\mathrm{mg} \cdot \mathrm{litre}^{-1}$; 256 measurements) and manganese (Mn, mg.litre ${ }^{-1} ; 245$ measurements, MSZ 1484-2:1993) contents. Because of the different numbers of the measurements we just took into account days, when we had all of the parameters measured. Therefore alkalinity was also not analysed here. By the in situ measurements, $\mathrm{pH}$ and conductivity (G) were measured with WTW pH/Cond 340i. Oxygen saturation $\left(\mathrm{O}_{2}\right)$ and water temperature were measured with Hach Lange termoluminescent dissolved oxygenmeter. By the laboratory measurements, after filtration (except COD and TP) a Fia Star 5000 set was used for nitrate $\left(\mathrm{NO}_{3}\right)$, nitrite $\left(\mathrm{NO}_{2}\right)$, orthophosphate $\left(\mathrm{PO}_{4}\right)$, total phosphorus (TP) and ammonium $\left(\mathrm{NH}_{4}\right)$. The mea- 
INFLUENCE OF METEOROLOGICAL VARIABLES TO WATER QUALITY IN FIVE LAKES OVER THE AGGTELEK (HUNGARY) ...

Tab. 1: Summarized description of the state of the lakes.

\begin{tabular}{|c|c|c|c|c|c|c|c|}
\hline Lake & $\begin{array}{l}\text { Pollution sources } \\
\text { (reason of the risk) }\end{array}$ & $\begin{array}{l}\text { Pollution } \\
\text { type }\end{array}$ & Pollution reflecting parameters & $\begin{array}{l}\text { Altitude } \\
\text { (m) }\end{array}$ & $\begin{array}{l}\text { Area } \\
\text { (ha) }\end{array}$ & $\begin{array}{l}\text { Maximal } \\
\operatorname{depth}(m)\end{array}$ & Trophity \\
\hline $\begin{array}{l}\text { Papverme } \\
\text { (Farárova } \\
\text { jama) }\end{array}$ & $\begin{array}{l}\text { Liquid manure } \\
\text { Urban runoff } \\
\text { Fishing Highway }\end{array}$ & $\begin{array}{l}\text { point } \\
\text { source, } \\
\text { diffuse }\end{array}$ & $\begin{array}{c}\text { Oxygen-establishment }\left(\mathrm{O}_{2} \%, \mathrm{CODps}\right) \\
\mathrm{P}-\mathrm{N}-\text { establishment }\left(\mathrm{PO}_{4}^{3-}: \text { summer, } \mathrm{TP},\right. \\
\mathrm{NO}_{3}^{-} \text {: autumn, spring, rainy periods, } \\
\mathrm{NO}_{2}^{-}, \mathrm{NH}_{4}^{+}, \text {chlorophyl-a ) other (Fe, } \\
(\mathrm{pH}, \mathrm{G}))\end{array}$ & 490 & 2.5 & 2.46 & eutrophic \\
\hline Aggteleki & $\begin{array}{l}\text { Internal and } \\
\text { external loads } \\
\text { from the sediment } \\
\text { Urban runoff }\end{array}$ & diffuse & $\begin{array}{l}\text { Oxygen-establishment }\left(\mathrm{O}_{2} \%, \mathrm{CODps}\right) \\
\text { P-N-establishment (TP, } \mathrm{PO}_{3^{\prime}}^{-}\left(\mathrm{NO}_{2^{\prime}}^{-}\right. \\
\mathrm{NH}_{4^{\prime}}^{+} \text {, chlorophyl-a)) other }\left(\mathrm{pH}, \mathrm{G}^{\prime}\right. \\
\mathrm{Fe}, \mathrm{Mn})\end{array}$ & 356 & 0.3 & 0.46 & $\begin{array}{l}\text { meso- } \\
\text { eutrophic }\end{array}$ \\
\hline Vörös & $\begin{array}{c}\text { Highway Geology } \\
\text { of the area }\end{array}$ & $\begin{array}{l}\text { particularly } \\
\text { natural } \\
\text { conditions } \\
\text { (possibly } \\
\text { point } \\
\text { source) }\end{array}$ & $\begin{array}{c}\text { Oxygen-establishment }\left(\mathrm{O}_{2} \%, \mathrm{CODps}\right) \\
\text { P-N-establishment }\left(\mathrm{TP}_{2}\left(\mathrm{PO}_{4}^{3-}, \mathrm{NO}_{2}^{-}\right.\right. \\
\mathrm{NH}_{4}^{+}, \text {chlorophyl-a) other }(\mathrm{Fe})\end{array}$ & 319 & 0.77 & 1.9 & mesotrophic \\
\hline Kender & $\begin{array}{l}\text { Internal load from } \\
\text { the sediment }\end{array}$ & $\begin{array}{c}\text { natural } \\
\text { conditions }\end{array}$ & $\begin{array}{c}\text { Oxygen-establishment }\left(\mathrm{O}_{2} \%, \mathrm{CODps}\right) \\
\text { P-N-establishment }\left(\mathrm{TP}_{2}\left(\mathrm{PO}_{4}^{3-}, \mathrm{NO}_{2^{\prime}}^{-}\right.\right. \\
\left.\left.\mathrm{NH}_{4}^{+}\right)\right) \text {other }(\mathrm{Fe},(\mathrm{Mn}))\end{array}$ & 349 & 0.4 & 0.7 & mesotrophic \\
\hline Tengerszem & $\begin{array}{l}\text { Catchment area of } \\
\text { the Cave Baradla } \\
\text { (e.g. fertilizers) }\end{array}$ & $\begin{array}{l}\text { point } \\
\text { source }\end{array}$ & $\begin{array}{c}\text { P-N-establishment }\left(\mathrm{NO}_{3}^{-}, \mathrm{PO}_{4}^{3-},\left(\mathrm{NH}_{4}^{+},\right.\right. \\
\text {TP) ) other }(\mathrm{G})\end{array}$ & 233 & 1.2 & 2.06 & oligotrophic \\
\hline
\end{tabular}

suring of iron and manganese contents was carried out with Perkin Elmer 3110 atomabsorbent and emission spectrometer.

Climatic parameters come from the meteorological station of Jósvafö, except for global solar flux originating from meteorological station of Edelény. The fol- lowing monthly means of the climate variables were considered: temperature $\left(\mathrm{T},{ }^{\circ} \mathrm{C}\right)$, global solar flux (GSF, $\left.\mathrm{J} \cdot \mathrm{cm}^{-2}\right)$, relative humidity $(\mathrm{RH}, \%)$, sea-level air pressure $(\mathrm{P}, \mathrm{hPa})$, wind speed (WS, $\left.\mathrm{m} \cdot \mathrm{s}^{-1}\right)$ and daily precipitation total (PT, mm). In Table 2. you can see a basic summary of the data set.

\begin{tabular}{l|r|r|r|r}
\hline & min & max & average & std. dev. \\
\hline $\mathrm{O}_{2}(\%)$ & 110.50 & 231.20 & 161.49 & 35.48 \\
\hline $\mathrm{COD}(\mathrm{mg} / \mathrm{l})$ & 5.77 & 35.78 & 13.66 & 6.70 \\
\hline $\mathrm{NO}_{3}^{-} / \mathrm{NO}_{2}-\mathrm{N}(\mathrm{mg} / \mathrm{l})$ & 0.00 & 1.93 & 0.24 & 0.55 \\
\hline $\mathrm{NO}_{2}-\mathrm{N}(\mathrm{mg} / \mathrm{l})$ & 0.00 & 0.09 & 0.02 & 0.02 \\
\hline $\mathrm{NH}_{4}^{+}-\mathrm{N}(\mathrm{mg} / \mathrm{l})$ & 0.00 & 1.15 & 0.35 & 0.33 \\
\hline $\mathrm{PO}_{4}^{3-} \mathrm{P}(\mathrm{mg} / \mathrm{l})$ & 0.00 & 0.85 & 0.12 & 0.21 \\
\hline $\mathrm{TP}-\mathrm{P}(\mathrm{mg} / \mathrm{l})$ & 0.00 & 1.13 & 0.31 & 0.25 \\
\hline $\mathrm{pH}$ & 7.26 & 10.18 & 8.96 & 0.55 \\
\hline $\mathrm{G}(4 \mathrm{~S} / \mathrm{cm})$ & 126.00 & 922.00 & 486.47 & 235.33 \\
\hline Fe (mg/l) & 0.01 & 2.93 & 0.45 & 0.63 \\
\hline $\mathrm{Mn}(\mathrm{mg} / \mathrm{l})$ & 0.00 & 0.87 & 0.10 & 0.22 \\
\hline Tair $\left({ }^{\circ} \mathrm{C}\right)$ & 3.90 & 23.50 & 15.92 & 5.38 \\
\hline prec. $(\mathrm{mm})$ & 0.00 & 18.10 & 2.17 & 5.28 \\
\hline air pressure (hPa) & 1007.50 & 1024.00 & 1018.36 & 4.46 \\
\hline windspeed $(\mathrm{km} / \mathrm{h})$ & 2.60 & 9.90 & 6.74 & 1.97 \\
\hline rel. hum. $(\%)$ & 41.50 & 88.20 & 64.35 & 15.63 \\
\hline global solar flux $(\mathrm{J} / \mathrm{cm} 2)$ & 212.90 & 2423.70 & 1677.53 & 820.61 \\
\hline
\end{tabular}

Table 2: Basic description of the data set 


\section{STATISTICAL METHODS}

\section{CLUSTER ANALYSIS}

Cluster analysis is a common statistical technique to objectively group elements such as water quality parameters using a similarity measure. The aim is to maximize the homogeneity of elements within the clusters and to maximize the heterogeneity among the clusters. Here a non-hierarchical cluster analysis with k-means algorithm using a Mahalanobis metric (Mahalanobis 1936) was applied. The Mahalanobis metric takes into account the different standard deviations of the components of the vectors to be clustered as well as the correlations among the components. We select the number of clusters under possible cluster numbers from 3 to 30 so as to ensure nearly uniform occurrence frequencies of the clusters. Intuitively, the final system of clusters produces a small variation of occurrence frequencies of the clusters constrained on forming these clusters by Ward's method (Anderberg 1973, Hair et al. 1998). Data to be clustered include values of the 11 water quality parameters considered.

The homogeneity within clusters was measured by RMSD defined as the sum of the root mean square deviations of cluster elements from the corresponding cluster centre over clusters. The RMSD will usually decrease with an increasing number of clusters. Thus, this quantity itself is not very useful for deciding about an optimal number of clusters. However, the change of RMSD (CRMSD) versus the change of cluster numbers, or even the change of CMRSD (CCRMSD) is much more informative. Therefore, working with cluster numbers from 15 to 1 , an optimal cluster number was selected so as to maximize the change in CRMSD. The rationale behind this approach is that the number of clusters producing the largest improvement in cluster performance compared to that for a smaller number of clusters is considered optimal (Makra et al. 2010).

Altogether 11 clustering procedures were implemented, based on the 11 water quality parameters considered. Clustering with the k-means algorithm was performed by MATLAB 7.5.0 software.

\section{FACTOR ANALYSIS AND SPECIAL TRANSFORMATION}

Factor analysis (FA) explains linear relationships among subsets of examined variables, which helps to reduce the dimensionality of the initial database without a substantial loss of information. First, 11 factor analyses was applied to the initial data sets (namely, to 11 resultant variables defined by the 11 water quality parameters involving in each case the 6 climatic elements as explanatory variables introduced in section 2.1) in order to transform the original variables to fewer variables. These new variables (called factors) can be viewed as latent variables explaining the joint behaviour of weather - water pollutant variables. The optimum number of the retained factors is determined with the criterion of reaching a prespecified percentage of the total variance (Jolliffe 1993). This percentage is chosen to be $80 \%$ in our case. After performing factor analysis, a special transformation of the factors retained was performed to find out to what degree the above-mentioned explanatory variables (6 climatic variables) affect the resultant variables (water quality parameters), and to give the rank of their influence (Jolliffe 1993; Jahn \& Vahle 1970).

\section{RESULTS}

\section{CLUSTER ANALYSIS}

Daily values of the climatic parameters observed were assigned to days of water quality measurements for each water quality parameter and then cluster averages of all variables were determined. Below, principally the clusters with extreme values of each water quality parameter will be considered and analysed in detail.

For Fe-content, four clusters were received. However, cluster 2 comprising a mere 2 days can be neglected. Of the remaining 3 clusters, cluster 2 indicates the highest, while cluster 3 the lowest $\mathrm{Fe}$-content. However, climatic parameters cannot be associated to these extreme values. Only temperature takes a minimum in cluster 2. Results of cluster analysis are only tabulated to Fe-content and climate variables (Tab. 3).

For the conductivity $(\mathrm{G})$, only three clusters were established. Conductivity is highest for cluster 1, involving the lowest temperature, global solar flux and relative humidity, as well as the highest wind speed; while it is lowest for cluster 2, comprising the highest temperature, global solar flux and relative humidity, as well as the lowest air pressure, wind speed and precipitation. More than four-fold difference in conductivity between clusters 1 and 2 can be difficult to explain by the differences in the ruling weather situations indicated by the extreme values of the climate parameters. 
For COD, three clusters were selected. However cluster 2, contrary to the fact that it comprises far the highest COD, involves only 7 days; hence it was omitted from further consideration. Among the remaining clusters, cluster 1 with the highest COD comprises the highest temperature, relative humidity, wind speed and precipitation, while cluster 3 with the lowest COD involves the lowest temperature, relative humidity and precipitation, as well as the highest global solar flux and air pressure. But here is not a big difference between the values of the 1 . and 3 . cluster so clear conclusions can't be drawn.

Tab. 3: Cluster-related mean values of the meteorological elements and Fe-content ( $m g \cdot$ litre ${ }^{-1}$ )

(bold: maximum; italic: minimum).

\begin{tabular}{|c|c|c|c|c|}
\hline Cluster & 1 & 2 & 3 & 4 \\
\hline Parameter & \multicolumn{4}{|c|}{ Mean values } \\
\hline Total number of days & 41 & 16 & 197 & 2 \\
\hline Frequency (\%) & 16.0 & 6.3 & 77.0 & 0.8 \\
\hline Temperature $\left({ }^{\circ} \mathrm{C}\right)$ & 15.1 & 12.6 & 13.8 & 17.7 \\
\hline Global solar flux $\left(\mathrm{J} \times \mathrm{cm}^{-2}\right)$ & 1362.0 & 1311.6 & 1329.7 & 1118.8 \\
\hline Relative humidity (\%) & 66.5 & 68.3 & 70.5 & 71.0 \\
\hline Air pressure (hPa) & 1015.6 & 1014.9 & 1014.0 & 1013.2 \\
\hline Wind speed $\left(m \times s^{-1}\right)$ & 5.9 & 5.4 & 5.4 & 5.1 \\
\hline Precipitation (mm) & 3.5 & 1.3 & 3.0 & 1.1 \\
\hline Fe (mg.litre $\left.{ }^{-1}\right)$ & 1.2 & 2.7 & 0.1 & 6.3 \\
\hline
\end{tabular}

For Mn-content, four clusters were established. However, clusters 2 and 4 involve only 5 and 1 elements, respectively. Hence, they are considered unimportant. Furthermore, cluster 1 comprises also a mere 13 days, assuming that results received for this cluster are also unfounded. In this way, only cluster 3 with 226 days was kept. For this cluster Mn-content was zero, with moderate values of the climatic elements.

For $\mathrm{NH}_{4}$-content, five clusters were received but clusters 1,2 and 5 with 1,2 and 4 days were omitted as negligible clusters. Accordingly, clusters 3 and 4 were retained with the two lowest $\mathrm{NH}_{4}$-contents. Of the climatic parameters only cluster 4 indicates extremities, namely relative humidity and precipitation are highest, while wind speed is lowest.

For $\mathrm{NO}_{2}$-content, three clusters were established but omitting cluster 3 that comprises only two days, actually clusters 1 and 2 with 0.0 and $0.1 \mathrm{mg} \cdot$ litre $^{-1}$ $\mathrm{NO}_{2}$-contents are difficult to enterpret by their extreme climate elements.

For $\mathrm{NO}_{3}$-content, three clusters were received. After excluding cluster 3 consisting of 6 days, the lowest $\mathrm{NO}_{3}$-content was found in cluster 1 characterised by the highest temperature, air pressure, wind speed and precipitation, as well as the lowest relative humidity. At the same time, high $\mathrm{NO}_{3}$-content of cluster 2 is not accompanied by extreme values of the climatic elements.

For $\mathrm{O}_{2}$-saturation, four clusters were got with a more uniform distribution of days than for the clusters mentioned before. Cluster 1 indicates the highest $\mathrm{O}_{2}$ saturation with the highest temperature, global solar flux and air pressure, as well as the lowest precipitation. While, the lowest $\mathrm{O}_{2}$-saturation of cluster 2 is presumably influenced by the lowest temperature, global solar flux, air pressure and wind speed, as well as by the highest relative humidity and precipitation.

For $\mathrm{pH}$, altogether four clusters were determined. The highest mean $\mathrm{pH}$ occurred in cluster 1 associated with the highest temperature and the lowest global solar flux. At the same time the lowest $\mathrm{pH}$ in cluster 3 is characterised by the lowest temperature, air pressure, wind speed and precipitation.

For $\mathrm{PO}_{4}$-content, three clsuters were established. However, cluster 1 comprising only one day is unimportant and, accordingly, is omitted. Cluster 2, with zero $\mathrm{mg} \cdot$ litre-1 $\mathrm{PO}_{4}$-content, involves the lowest temperature and wind speed, as well as the highest relative humidity and precipitation. On the other hand, cluster 3 with non-zero $\mathrm{PO}_{4}$-content is characterised by the lowest global solar flux and air pressure, as well as the highest wind speed.

For TP-content, four clusters were received. However, cluster 2 comprising only a mere day was excluded from further consideration. In this way cluster 1 involved the highest TP-content, with the highest temperature, global solar flux, wind speed and precipitation. At the same time cluster 3, with the lowest TPcontent, comprises the lowest air pressure.

\section{THE RANKED FACTOR ANALYSIS}

Factor analysis was performed for each water quality parameter as resultant variable including all six climatic parameters as explanatory variables. Hence, for each of the 11 resultant variables comprising the same six explanatory variables, altogether 11 factor analyses were carried out. All factor analyses resulted in four factors. Eigenvalues, variance explained and cumulative variance are also presented for each factor. Furthermore, factor loadings significant for $95 \%$ and $99 \%$ probability levels are indicated.

After performing factor analysis, special transformation was implemented in order to determine the weight of the explanatory variables and, in this way their rank of importance in forming the resultant variables.

For Fe-content, the role of air pressure and temperature are apparently the most important, while relative 
humidity and wind speed indicate the lowest weight. Despite of this non of the climatic parameter's factor loading indicates significant effect on influencing the Fe-content. It seems that the concentration of $\mathrm{Fe}$ in the water influences mainly the geology of the area (the amount of red and yellow clay on more places). Results of factor analysis and special transformation are only presented to Fe-content and climate variables (Tabs. 4 and 5).

In influencing the conductivity $(\mathrm{G})$, the air pressure is the only significant leading factor.

For COD, global solar flux and air pressure have the highest impact, in the first case the significant relation is positive (in 99\% probability level) and in the second case it is a negative relation on $95 \%$ probability level. In the first case if the global solar flux is higher, the produduction capacity of organic matter in the water is greater too. This means also a stronger process than if with the lower air pressure it starts to rain and it could wash more organic matter into the lake.

For Mn-content non of the climatic variables playes an important role. The reason is probably like by the Fe-content, the geology of the area is more important. For $\mathrm{NH}_{4}^{+}$-content, air pressure has the highest weight, the growth of this brings also highest $\mathrm{NH}_{4}^{+}$concentrations. For $\mathrm{NO}_{2}$-content, temperature and air pressure are the leading factors, but it has also positive significant relations with the global solar flux and the precipitation.

In the infuencing of the $\mathrm{NO}_{3}$-content every climatic parameter has a significant effect, air pressure and temperature are the most important variables, while role of the precipitation, relative humidity and wind speed is weakest. This means that in affecting the $\mathrm{NO}_{3}$-concentrations the role of weather situations is remarkable.

For $\mathrm{O}_{2}$-saturation, global solar flux and air pressure have the highest role, but except the precipitation effect of the other parameters can't be neglected too. The influence of the global solar flux is that if it is higher, the algal photoshyntesis is also more active.

For $\mathrm{pH}$, wind speed and air pressure are the most important, but effect of the relativ humidity is also significant (negative relation). The reason of stronger connection with the wind speed can be the mixing generated by the wind.

For $\mathrm{PO}_{4}$-content the situation is similar to the $\mathrm{pH}$ but it has positive connection only with the wind speed. Meanwhile for TPcontent effect of the climatic parameters can be disregarded - here other processes overwrite them.

Following factor analyses and special transformations, the ranks of impor-

Tab. 5: Special transformation. Effect of the explanatory variables on water quality ( $\mathrm{Fe}$-content, $m g \cdot$ litre $^{-1}$ ) as resultant variable and the rank of importance of the explanatory variables on their factor loadings transformed to Factor 1 for determining the resultant variable

(thresholds of significance: italic: $x_{0.95}=0.122$; bold: $x_{0.99}=0.160$ ).

\begin{tabular}{|c|c|c|}
\hline Variables & weight & rank \\
\hline Fe-content (mg.litre-1) & 0.996 & - \\
\hline Temperature $\left({ }^{\circ} \mathrm{C}\right)$ & 0.078 & 2 \\
\hline Global solar flux $\left({\left.\mathrm{J} \times \mathrm{cm}^{-2}\right)}^{-2}\right.$ & -0.048 & 4 \\
\hline Relative humidity (\%) & -0.014 & 5 \\
\hline Air pressure (hPa) & 0.091 & 1 \\
\hline Precipitation (mm) & -0.067 & 3 \\
\hline Wind speed $\left(\mathrm{m} \times \mathrm{s}^{-1}\right)$ & 0.002 & 6 \\
\hline
\end{tabular}

tance of the meteorological variables are averageed for each of the eleven water quality parameter as resultant variables (Tab. 6).

According to the table, the meteorological variables indicate different weights in influencing the resultant parameters. Based on the mean ranks, air pressure (1.82), global solar flux (3.36) and temperature (3.45) are considered the most important, while relative humidity (3.91), wind speed (3.91) and precipitation (4.55) are the least relevant variables influencing water quality parameters in general (Table 6, last column).

The 11 resultant variables seem too many, since 11 factor analyses and after performing them, 11 special transformations should be performed in order to receive the rank of importance of the meteorological 
Tab. 6: Special transformation. The rank of importance of the explanatory variables on their factor loadings transformed to Factor 1 for determining the water quality parameters as resultant variables (thresholds of significance: italic: significant for 95\% probability level; bold: significant for $99 \%$ probability level).

\begin{tabular}{|c|c|c|c|c|c|c|c|c|c|c|c|c|}
\hline \multirow{3}{*}{$\begin{array}{l}\text { Explanatory } \\
\text { variables }\end{array}$} & \multicolumn{11}{|c|}{ Resultant variables } & \multirow[b]{2}{*}{$\begin{array}{l}\text { mean } \\
\text { rank }\end{array}$} \\
\hline & $\begin{array}{l}\mathrm{O}_{2} \\
\% \\
\end{array}$ & $\begin{array}{l}\mathrm{COD} \\
\mathrm{mg} / \mathrm{l}\end{array}$ & $\begin{array}{l}\mathrm{NO}_{3} \\
\mathrm{mg} / \mathrm{l}\end{array}$ & $\begin{array}{l}\mathrm{NO}_{2} \\
\mathrm{mg} / \mathrm{l}\end{array}$ & $\begin{array}{l}\mathrm{PO}_{4} \\
\mathrm{mg} / \mathrm{l}\end{array}$ & $\begin{array}{c}\mathrm{TP} \\
\mathrm{mg} / \mathrm{l}\end{array}$ & $\begin{array}{l}\mathrm{NH}_{4} \\
\mathrm{mg} / \mathrm{l}\end{array}$ & $\mathrm{G} \mu \mathrm{S} / \mathrm{cm}$ & $\begin{array}{c}\mathrm{Fe} \\
\mathrm{mg} / \mathrm{l}\end{array}$ & $\begin{array}{c}\mathrm{Mn} \\
\mathrm{mg} / \mathrm{l}\end{array}$ & $\mathrm{pH}$ & \\
\hline & \multicolumn{12}{|c|}{ Rank of importance } \\
\hline $\begin{array}{l}\text { Temperature } \\
\left({ }^{\circ} \mathrm{C}\right)\end{array}$ & 3 & 3 & 2 & 1 & 6 & 6 & 2 & 4 & 2 & 5 & 4 & 3.45 \\
\hline $\begin{array}{l}\text { Global solar } \\
\text { flux }\left(\mathrm{J} / \mathrm{cm}^{2}\right)\end{array}$ & 1 & 1 & 3 & 3 & 5 & 2 & 3 & 5 & 4 & 4 & 6 & 3.36 \\
\hline $\begin{array}{l}\text { Relative } \\
\text { humidity (\%) }\end{array}$ & 4 & 6 & 5 & 6 & 3 & 4 & 4 & 2 & 5 & 1 & 3 & 3.91 \\
\hline $\begin{array}{l}\text { Air pressure } \\
(\mathrm{hPa})\end{array}$ & 2 & 2 & 1 & 2 & 2 & 3 & 1 & 1 & 1 & 3 & 2 & 1.82 \\
\hline $\begin{array}{l}\text { Precipitation } \\
(\mathrm{mm})\end{array}$ & 6 & 5 & 4 & 4 & 4 & 5 & 5 & 3 & 3 & 6 & 5 & 4.55 \\
\hline $\begin{array}{l}\text { Wind speed } \\
(\mathrm{m} / \mathrm{s})\end{array}$ & 5 & 4 & 6 & 5 & 1 & 1 & 6 & 6 & 6 & 2 & 1 & 3.91 \\
\hline
\end{tabular}

variables in determining the 11 water quality parameters. In order to save calculations, a so called twostage (or ranked) factor analysis is performed. Firstly, factor analysis is implemented for the 11 water quality parameters, where 5 Factors were retained that explain $82.81 \%$ of the total variance of the initial data set (Tab. 7).

These factors comprise different weights of the original water quality parameters; hence they cannot be represented by clear effects of a given resultant variable. Factor 1 correlates highly with $\mathrm{COD}, \mathrm{NH}_{4}^{-}$ and $\mathrm{PO}_{4}$-contents; Factor 2 consists of high loadings for $\mathrm{NO}_{3}$ - and Fe-contents; Factor 3 indicates strong connection with $\mathrm{O}_{2}$-saturation; Factor 4 is mostly determined by NO- and TP-contents and Factor 5 has

Tab. 7: Factor loadings of the component matrix, combined water quality variables (thresholds of significance: italic: $x_{0.95}=0.195$; bold: $x_{0.99}=0.254$ ).

\begin{tabular}{|c|c|c|c|c|c|}
\hline Water quality variables & Factor 1 & Factor 2 & Factor 3 & Factor 4 & Factor 5 \\
\hline $\mathrm{O}_{2}(\%)$ & 0.057 & -0.311 & 0.841 & 0.057 & 0.129 \\
\hline COD (mg.litre $\left.{ }^{-1}\right)$ & 0.813 & -0.380 & 0.059 & 0.143 & 0.164 \\
\hline $\mathrm{NO}_{3}\left(\mathrm{mg} \cdot\right.$ litre $\left.^{-1}\right)$ & -0.133 & 0.869 & -0.005 & 0.125 & 0.183 \\
\hline $\mathrm{NO}_{2}\left(\mathrm{mg} \cdot\right.$ litre $\left.{ }^{-1}\right)$ & 0.161 & 0.577 & 0.045 & 0.567 & 0.478 \\
\hline $\mathrm{NH}_{4}\left(\mathrm{mg} \cdot\right.$ litre $\left.^{-1}\right)$ & 0.816 & 0.177 & -0.305 & 0.065 & -0.051 \\
\hline $\mathrm{PO}_{4}\left(\mathrm{mg} \cdot\right.$ litre $\left.^{-1}\right)$ & 0.908 & 0.092 & -0.225 & -0.078 & -0.106 \\
\hline TP (mg.litre-1) & -0.035 & 0.134 & -0.028 & -0.722 & 0.646 \\
\hline $\mathrm{pH}$ & 0.325 & -0.220 & 0.839 & 0.107 & 0.117 \\
\hline $\mathrm{G}\left(\mu \mathrm{S} \cdot \mathrm{cm}^{-1}\right)$ & 0.534 & 0.645 & 0.247 & -0.221 & -0.228 \\
\hline Fe (mg.litre $\left.{ }^{-1}\right)$ & 0.040 & -0.612 & -0.574 & 0.262 & 0.344 \\
\hline Mn (mg.litre $\left.{ }^{-1}\right)$ & 0.530 & -0.229 & -0.065 & -0.241 & 0.070 \\
\hline Eigenvalue & 2.871 & 2.278 & 1.955 & 1.079 & 0.926 \\
\hline Variance explained, $\%$ & 26.104 & 20.705 & 17.771 & 9.810 & 8.417 \\
\hline Cumulative variances, \% & 26.104 & 46.809 & 64.580 & 74.390 & 82.807 \\
\hline
\end{tabular}

the highest factor loadings for $\mathrm{NO}_{2}$ - and TP-contents (Tab. 7).

Then, again, factor analyses were applied on the one hand to the factor score time series of Factors 1, $2, \ldots, 5$, and the original data of the six meteorological variables on the other. Afterwards, special transformations were carried out for the factor loadings of the five factors and for those of the meteorological variables.

The ranks of importance of the meteorological variables in determining the factors, are averaged for each factor as resultant variable (Tab. 8).

According to the table, the meteorological variables indicate different weights in influencing the factors, with the lowest mean rank for tenperature (2.40) and relative humidity (2.60) and the highest mean rank for air pressure (4.00) and global solar flux (4.40) indicating the most and least important explanatory variables respectively, influencing the factors overall (Table 6, last column). 
Tab. 8: Special transformation. The rank of importance of the explanatory variables on their factor loadings transformed to Factors 1, 2, 3, 4 and 5 for determining the combined water quality variables as resultant variables (thresholds of significance: italic: significant for 95\% probability level; bold: significant for 99\% probability level).

\begin{tabular}{|c|c|c|c|c|c|c|}
\hline \multirow{3}{*}{ Explanatory variables } & \multicolumn{5}{|c|}{ Combined resultant variables } & \multirow[t]{2}{*}{ mean rank } \\
\hline & Factor 1 & Factor 2 & Factor 3 & Factor 4 & Factor 5 & \\
\hline & \multicolumn{6}{|c|}{ Rank of importance } \\
\hline Temperature $\left({ }^{\circ} \mathrm{C}\right)$ & 2 & 5 & 1 & 1 & 3 & 2.40 \\
\hline Global solar flux $\left({\left.\mathrm{J} \times \mathrm{cm}^{-2}\right)}^{-2}\right.$ & 4 & 6 & 4 & 6 & 2 & 4.40 \\
\hline Relative humidity (\%) & 1 & 1 & 2 & 4 & 5 & 2.60 \\
\hline Air pressure $(\mathrm{hPa})$ & 5 & 3 & 6 & 5 & 1 & 4.00 \\
\hline Precipitation (mm) & 3 & 4 & 3 & 3 & 6 & 3.80 \\
\hline Wind speed $\left(\mathrm{m} \times \mathrm{s}^{-1}\right)$ & 6 & 2 & 5 & 2 & 4 & 3.80 \\
\hline
\end{tabular}

\section{DISCUSSION AND CONCLUSIONS}

After describing the association between cluster-related values of the water quality parameters influenced by climatic variables, we are going to gain a deeper insight in this topic. In this study we dealt only with the prevailing weather conditions occurring on the water quality measurement days, analyzing the longer effects of the meteorological situations exceeds the framework of this study. Of course the method ensures more precise results when there are more measurement days, but our possibilities were limited. With the growing frequency of weather extremities higher instability and harder regeneration of the shallow lakes should be taken into account. Therefore studies that examine the effects of weather events on the lakes' water quality are of particular importance - with the help of these results actions could be taken against the phenomenon. There are some water quality parameters that correlate less with the climatological parameters: the higher concentration of these can be in stronger connection with anthropogenic activity or the geology of the area. But most of the chemical parameters are highly correlated with the weather conditions - this means unstable and extreme weather conditions (drought and wet periods as well) act in the direction of breaking up the balance that would support the good water quality (IPCC 2007). This process is not favourable for the water use and the sensitive karst hydrogeological system. Since these lakes are quite small and shallow, the anthropogenic activity and the weather situations influence them in a considerable degree, except of some components like Fe or Mn, in which case geology plays a more characteristic role. The weather situations affect the water quality already in a short time period. This strengthens the pollution effects as well: in the case of lakes where direct inflow can be found, the bigger precipitation events are responsible for the increased pollution, while in case there is absence of direct inflow, the drier periods with high global solar flux are responsible for the same phenomenon.

In general maximum values of a given water quality parameter occur more frequently on the area if global solar flux, air pressure and precipitation are at minimum and relative humidity is at maximum. Accordingly, maximum values of water quality parameters can be associated with a weak warm front passing through over the region that assists the enrichment of the given factor. At the same time, minimum values of a given water quality parameter take place more often if global solar flux and relative humidity are at the maximum, while air pressure and wind speed are at the minimum. These values assume post - warm front weather situations that are possibly developing to anticyclone ridge weather situations that facilitate the dilution of the given factor. As a result, both maximum and minimum values of the water quality parameters considered can be associated with mixed weather conditions, or more likely with weak or disbanded warm fronts.

Average rank of importance of the climatic variables calculated were based on all water quality parameters in order to find out which climatic variables have the highest/lowest impact on determining the resultant variables in general. The lowest the average of the rank of importance, the highest the role of the climatic parameter is. According to this, air pressure, global solar flux and temperature are the most important factors, while relative humidity, wind speed and precipitation are irrelevant in general, in forming the water quality parameters as resultant variables. Precipitation occurs here probably because on the given days there is not a big difference in the amounts registered. But also according to Malík 
(2006) precipitation totals in a year show slighter decrease, therefore the increased evaporation as a result of increased air temperature plays more important role. A study carried out between 1981-2000 (Kullman \& Chalupka 1995; Malík 2006) shows that the decreased level of groundwater supply - resulting in reduced level of water supply and drying out of lakes - is caused by the decreased amount of snow and the evaporation. Consequently, it is confirmed that compared to the other climatic parameters, air pressure and global solar flux complemented with temperature has a primary role. The mentioned parameters affect also the COD and oxygen saturation and these parameters vary on the given days considerably. This presumably contributes to the intensification of the organic matter production and oxygen lack in the lakes which is by shallow eutrophic lakes quite important and that reflect the water quality parameters connected to this process. As a result of the higher temperature and the ggincreased plant amount caused by eutrophication, the evaporation is stronger as well which also means a quantitative loss of water.

According to the average ranks of importance of the meteorological variables in determining the factors - the resultant variables include the combined results of the water quality parameters - temperature and relative humidity are the most significant, while air pressure and global solar flux are the least relevant explanatory variables in determining the five factors overall.

Application of the two-stage factor analysis involves both benefits and disadvantages. Its benefit is that it substantially reduces the number of resultant variables. In this way, information loss of the retained factors is around $20 \%$. Since the resultant variables for the two approaches are partly the eleven water quality parameters and partly the five factors that can be interpreted as combined water quality variables, the difference in mean ranks of importance of the meteorological variables determining the resultant variables cannot be compared.

The study introduces a novel methodology for analysing the climate impact of water quality parameters. Application of ranked factor analysis is a novel procedure. Furthermore, introducing a two-stage factor analysis in order to reduce the number of the resultant variables is a novel approach. To show clearer tendencies in the results more water quality monitoring days are needed, but the introduced statistical method can be useful for analysing the water chemistry-climate connections.

\section{ACKNOWLEDGEMENTS}

The research was funded by the TÁMOP-4.2.1/B-09/1/

KONV-2010-0005.

\section{REFERENCES}

Anderberg, M.R., 1973: Cluster Analysis for Applications. Academic Press, pp. 359, New York.

Barančok, P., 2001: Karst lakes of the protected landscape area - Biosphere Reserve Slovensky kras karst and Aggtelek National Park.- Ekol Bratislava 20, 4, 157-190.

Bárány-Kevei, I., 1999: Land Degradation on some Hungarian Karst. In: Coelho, C. (ed.): Proceedings of The International Seminar on Land Degradation and Desertification. IGU Regional Conference, Aveiro 77-83.

Cílek, V., 1996: Silica - zrození a smrt jezera. Podarí se zachránit Jašteričie jazierko na Silické planině ve Slovenském krasu?- Speleoforum, 15, 36-42.
Czesznak, L., 2000: Az Aggteleki-tó rehabilitációs munkálatainak előzetes környezeti hatástanulmánya. Project Report - Hegyvidéki Tavainkért Környezetvédelmi Egyesület, Miskolc 34 p.

Dillon, P.J. \& F.H. Rigler, 1974: The phosphorus-chlorophyll relationship in lakes.- Limnology and Oceanography, 19, 767-773.

Gaál, L., 2010: Gömörország természeti öröksége. GömörKishonti Múzeum Egyesület, pp. 208, Rimaszombat.

Háberová, I. \& E. Karasová, 1991: Hydroséria vegetácie Jašteričieho jazera na Silickej planine.- Ochrana Prírody 11, 298-307. 
Hair, J.F., Anderson, R.E., Tatham, R.L. \& W.C. Black, 1998: Multivariate data analysis. Prentice Hall, pp. 732, New Jersey.

Haviarová, D., Fl'aková, R., Seman, M. \& Z. Ženišová, 2010: Chemické zloženie a mikrobiologické vlastnosti krasových vôd Silicko-Gombaseckého jaskynného systému (Silická planina, Slovenský kras). Abstract: 8. vedecká konferencia Výskum, využívanie a ochrana jaskýň - Demänovská Dolina 4. - 6. 10. 2011/ 8th scientific Conference Research, Use and Protection of Caves - Demänovská valley, October 4-6, 2011.

Horváth, L., 2009: Alkalmazkodási kihívások és eszközök az éghajlatváltozási kerettörvényben. Project report - Nemzeti Fenntartható Fejlödési Tanács, Budapest, pp. 35.

Horváth, L., 2010: Felkészülés a klímaváltozásra - alkalmazkodás.- Nemzet és Biztonság 2, 67-82.

Huber, A., 2006: Az aggteleki Vörös-tó élőhely-rehabilitációja. Project report, Aggtelek National Park, Aggtelek, Hungary, pp. 4.

Hudec, I., Belánová, A., M. Uhrin, 1993: Poznámky k eutrofizácii a zooplanktón Jašteričieho jazera a Farárovej jamy (Slovenský kras) v roku 1992.Zborník Východoslovenského Múzea v Košiciach, Prírodné vedy 34, 67-72.

Hudec, I., Košel, V. \& M. Rozložník, 1995: Human impacts on eutrophication and extinction of Lake Jašteričie (Biosphere reserve-Slovak karst).- Ekol. Bratislava 14, 4, 449-466.

IPCC, 2007: Climate Change 2007: Synthesis Report. Intergovernmental Panel on Climate Change (IPCC).

Jahn, W. \& H. Vahle, 1970: Die Faktoranalyse und ihre Anwendung. Verlag die Wirtschaft, pp. 228, Berlin.

Jakucs, L., 2001: Aggtelek természeti képe. In: Bódisné, J.I., Dénes, G. \& L. Jakucs (ed.): Aggtelek a magyar állam alapitásának ezredik évében. Aggtelek Község Önkormányzata. pp. 7-38, Aggtelek.

Jolliffe, I.T., 1993: Principal component analysis: A beginner's guide - II. Pitfalls, myths and extensions.Weather 48, 246-253.

Juhász, L. \& G. Salamon, 2006: A Jósvafői Tengerszem-tó halközössége. XXX. Halászati Tudományos Tanácskozás, Szarvas, Abstract, 41 p.

Kaliser, B., 1995: Hydrogeologic investigation of Lizard Lake, Silica Plateau, Slovak Karst. Project report - Slovak Karst National Park \& US Peace Corps, VOCA, Bratislava, pp. 60.

Kilík, J., 2010: Povrchové a podzemné vody Silickej planiny (Slovenský kras).- Aragonit 15, 1, 11-19.
Kullman, E. \& J. Chalupka, 1995: Pokles výdatnosti zdrojov podzemných vôd na Slovensku a hodnotenie jeho príčin- Podzemná voda, Slovenská asociácia hydrogeológov Bratislava, 1, 58-74.

Kunský, J., 1939: Jezera Slovenskeho krasu.- Rozpravy II. Třídy České Akademie, r. XLIX, 25, 1-17.

Lund, J.W.G., 1970: Primary production.- Water Treatment and Examination, 19, 332-358.

Mahalanobis, P.C., 1936: On the generalized distance in statistics.- Proceedings of the National Institute of Science of India 12, 49-55.

Makra, L., Sánta, T., Matyasovszky, I., Damialis, A., Karatzas, K., Bergmann, K.C. \& D. Vokou, 2010: Airborne pollen in three European cities: Detection of atmospheric circulation pathways by applying three-dimensional clustering of backward trajectories.- Journal of Geophysical Research - Atmospheres, 115, D24220, doi: 10.1029/2010JD014743.

Malík, P., 2006: Changing environment of wetlands on the top of a karstic plateau in southern Slovakia (Central Europe). In: Durán, J.J., Andreo, B. \& F. Carrasco (Eds.): Karst, climate change and groundwater. Publicaciones del Instituto Geológico y Minero de España. Serie: Hidrogeología y Aguas Subterráneas, Madrid, 18, pp. 395-407.

McKee, T.B., Doesken, N. J. \& J. Kliest, 1993: The relationship of drought frequency and duration to time scales. In: Proceedings of the 8th Conference of Applied Climatology, 17-22 January, Anaheim, CA. American Meterological Society, Boston, MA. pp. 179-184.

OECD (Organization for Economic Cooperation and Development), 1982: Eutrophication of Waters. Monitoring assessment and control. Final Report. OECD Cooperative Programme on Monitoring of Inland Waters (Eutrophication Control). Environment Directorale, OECD, Paris, p. 1-154.

Oglesby, R.T. \& W.R. Schaffner, 1975: The response of lakes to phosphorus. In: Porter, S.K. (ed.): Nitrogen and Phosphorus. Food production. Waste and the environment. pp 23-57.

Samu, A., Kiss, M., \& E. Tanács, 2010: Környezeti változások modellezése Bayes hálók segítségével, karsztos tavak eutrofizációjának példáján. In: Kertész Á, Jakab G, Madarász B, Örsi A, Pálinkás M (eds.): Tájökológiai kutatások 2010: IV. Magyar Tájökológiai Konferencia: Kerekegyháza, 2010. május 13-15. Kerekegyháza, Magyarország. MTA Földrajztudományi Kutatóintézet, pp. 239-245., Budapest ( ISBN: 978-963-9545-31-1). 
Tanács, E. \& I. Bárány-Kevei, 2010: Patterns of tree species composition and their relation with climate and past forest management in Haragistya-Lófej forest reserve (Aggtelek Karst, Hungary) in: Ostapowicz, K. \& Kozak, J. (Eds.): Conference Proceedings of the 1st Forum Carpaticum, Integrating Nature and Society Towards Sustainability, pp. 64-65, Krakow.

Tanács, E., 2011: Temperature and precipitation trends in Aggtelek Karst (Hungary) 1958-2008.- Acta Climatologica et Chorologica 44-45, 51-63.

Terek, J., 2003: Ekologicky stav jazier Slovenskeho krasu. In: Midriak R. (ed.): Biosférické rezervácie na Slovensku IV : zborník referátov zo 4. národnej konferencie "25. výročie vyhlásenia prvej slovenskej Biosférickej rezervácie Slovenský kras" konanej v Rožňave 28.29.10.2002. Technická univerzita vo Zvolene - ISBN 80-228-1222-6., 185-188, Zvolen.
Tereková, V., 1984: Príčiny a dôsledky znečistovania Jašteričieho jazera v Slovenskom krase.- Slovenský kras 22, 131-141.

Ujvárosy, A., 1998: Földrajzi helyzet, éghajlati viszonyok.- In Baross G. (ed.) Az Aggteleki Nemzeti Park. Mezőgazda Kiadó pp 22-26, Budapest.

Vollenweider, R.A., 1968: The scientific basis of lake eutrophication with particular reference to phosphorus and nitrogen as eutrophication factors. OECD, Paris, Tech. Rep. DAS/DSI 68.27, pp. 159.

Vollenweider, R.A. \& J. Kerekes, 1982: Eutrophication of waters. Monitoring, assessment and control. OECD Cooperative programme on monitoring of inland waters (Eutrophication control), Environment Directorate, OECD, pp. 154, Paris. 